\title{
The BDNF Val66Met Polymorphism Impairs NMDA Receptor-Dependent Synaptic Plasticity in the Hippocampus
}

\author{
Ipe Ninan, ${ }^{1}$ Kevin G. Bath, ${ }^{4}$ Karishma Dagar, ${ }^{2}$ Rosalia Perez-Castro, ${ }^{2}$ Mark R. Plummer, ${ }^{3}$ Francis S. Lee, ${ }^{4}$ \\ and Moses V. Chao ${ }^{2}$ \\ ${ }^{1}$ Department of Psychiatry and ${ }^{2}$ Neurobiology Program, Skirball Institute, New York University School of Medicine, New York, New York 10016, \\ ${ }^{3}$ Department of Cell Biology and Neuroscience, Rutgers University, Piscataway, New Jersey 08854, and ${ }^{4}$ Department of Psychiatry, Weill Medical College of \\ Cornell University, New York, New York 10065
}

The Val66Met polymorphism in the brain-derived neurotrophic factor (BDNF) gene results in a defect in regulated release of BDNF and affects episodic memory and affective behaviors. However, the precise role of the BDNF Val66Met polymorphism in hippocampal synaptic transmission and plasticity has not yet been studied. Therefore, we examined synaptic properties in the hippocampal CA3-CA1 synapses of $\mathrm{BDNF}^{\mathrm{Met} / \mathrm{Met}}$ mice and matched wild-type mice. Although basal glutamatergic neurotransmission was normal, both young and adult mice showed a significant reduction in NMDA receptor-dependent long-term potentiation. We also found that NMDA receptordependent long-term depression was decreased in $\mathrm{BDNF}^{\mathrm{Met} / \mathrm{Met}}$ mice. However, mGluR-dependent long-term depression was not affected by the BDNF Val66Met polymorphism. Consistent with the NMDA receptor-dependent synaptic plasticity impairment, we observed a significant decrease in NMDA receptor neurotransmission in the CA1 pyramidal neurons of BDNF ${ }^{\mathrm{Met} / \mathrm{Met}}$ mice. Thus, these results show that the BDNF Val66Met polymorphism has a direct effect on NMDA receptor transmission, which may account for changes in synaptic plasticity in the hippocampus.

\section{Introduction}

Brain-derived neurotrophic factor (BDNF), a neurotrophin highly expressed in the hippocampus, has been implicated in hippocampus-dependent cognitive functions (Hariri et al., 2003; Bekinschtein et al., 2008). Consistent with this role, BDNF modulates synaptic neurotransmission, neuronal excitability, and synaptic plasticity (Korte et al., 1995; Patterson et al., 1996; Tyler and Pozzo-Miller, 2001; Yano et al., 2006). Also, mice lacking the $\mathrm{BDNF}$ receptor, TrkB, and mice with targeted mutation in the PLC $\gamma$ site of TrkB show abnormal hippocampal long-term potentiation (LTP) (Minichiello et al., 1999, 2002).

A role for BDNF in learning and memory is further supported by the recent finding that the BDNF Val66Met polymorphism impairs episodic memory and hippocampal function (Egan et al., 2003; Hariri et al., 2003; Chen et al., 2006). Recently, it was reported that the BDNF Val66Met polymorphism alters fear extinction learning in both humans and mice (Soliman et al., 2010). The BDNF Val66Met polymorphism affects intracellular trafficking of pro-BDNF and alters the regulated release of BDNF (Egan et al., 2003; Chen et al., 2006). Measurement of BDNF levels in $\mathrm{BDNF}^{\mathrm{Met} / \mathrm{Met}}$ mice revealed $\sim 30 \%$ reduction in regulated release

Received March 18, 2010; revised May 12, 2010; accepted May 18, 2010.

This work was supported by the Sackler Institute (K.G.B.), DeWitt-Wallace Fund of the New York Community Trust (F.S.L.), Burroughs Wellcome Foundation (F.S.L.), National Alliance for Research on Schizophrenia and Depression (I.N.), and National Institutes of Health Grants NS-21072 (M.V.C.), MH060478 (K.G.B.), MH079513 (F.S.L.), and NS052819 (F.S.L.).

Correspondence should be addressed to Ipe Ninan, Department of Psychiatry, New York University School of Medicine, 540 First Avenue, New York, New York 10016. E-mail: ipe.ninan@nyumc.org.

DOI:10.1523/JNEUROSCI.1405-10.2010

Copyright $\odot 2010$ the authors $\quad 0270-6474 / 10 / 308866-05 \$ 15.00 / 0$ of BDNF (Chen et al., 2006). This BDNF release abnormality is likely to be due to the altered binding of BDNF ${ }^{\mathrm{Met}}$ to sortilin, a sorting protein that interacts with BDNF in the prodomain region (Chen et al., 2005).

A variety of studies have implicated the BDNF Val66Met polymorphism in neuropsychiatric disorders such as schizophrenia, Alzheimer's disease, and affective disorders (Ventriglia et al., 2002; Chen et al., 2006; Rybakowski, 2008; Verhagen et al., 2010). Although these studies suggest a correlative role for BDNF in hippocampal functions, whether an impairment in the regulated release of BDNF affects synaptic neurotransmission and plasticity in the hippocampus has not been explored in depth. We therefore examined whether the BDNF Val66Met polymorphism affects synaptic plasticity at the CA3-CA1 synapses using BDNF ${ }^{\text {Met }}$ knock-in mice (BDNF $\left.{ }^{\mathrm{Met} / \mathrm{Met}}\right)$. We find that $\mathrm{BDNF}^{\mathrm{Met} / \mathrm{Met}}$ mice exhibit a decrease in hippocampal synaptic plasticity that depends upon the activation of NMDA receptors.

\section{Materials and Methods}

Animals. BDNF ${ }^{\mathrm{Met} / \mathrm{Met}}$ mice were maintained on an inbred $\mathrm{C} 57 \mathrm{BL} / 6$ background (Chen et al., 2006). BDNF ${ }^{\mathrm{Met} / \mathrm{Met}}$ female mice and wild-type littermates derived from heterozygous $\mathrm{BDNF}^{+/ \mathrm{Met}}$ parents were used for all experiments. All animals were kept on a $12: 12$ light-dark cycle at $22^{\circ} \mathrm{C}$ with food and water available ad libitum. All experiments were performed in accordance with institutional guidelines. Mice were genotyped as described previously (Chen et al., 2006).

Field EPSP recording. Mice were decapitated after pentobarbital anesthesia. Brains were quickly removed and hippocampi were cut into 300 $\mu \mathrm{m}$ transverse slices with a tissue chopper and maintained at room temperature for $90 \mathrm{~min}$ in a brain slice keeper before transferring to an interface recording chamber maintained at $32^{\circ} \mathrm{C}$ in artificial CSF (ACSF) 
A

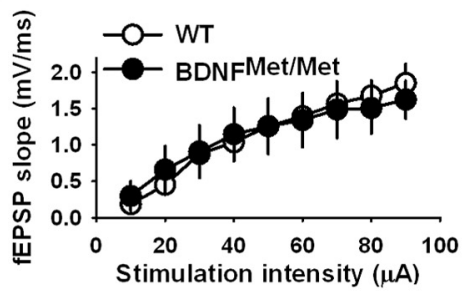

C

WT

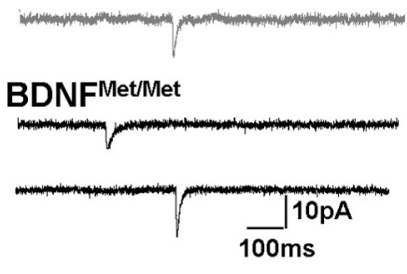

$\mathbf{F}$

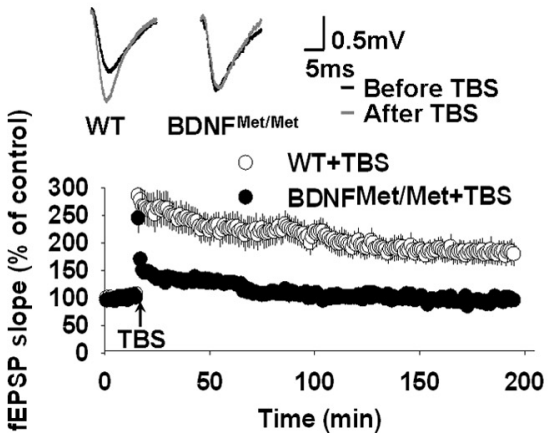

B

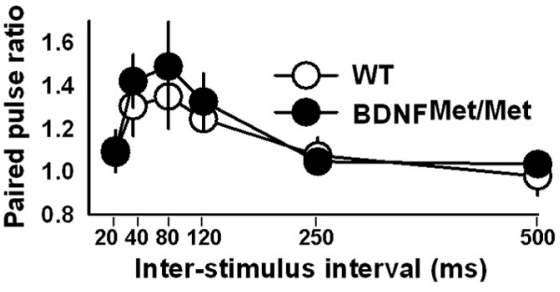

E

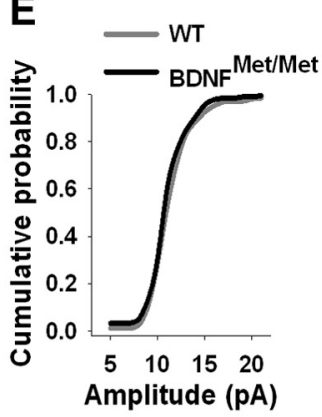

G

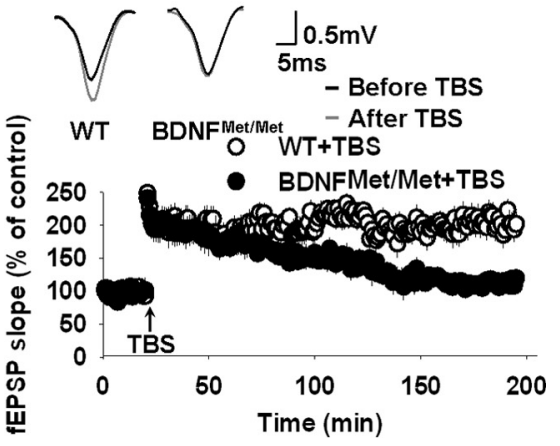

Figure 1. Basal synaptic neurotransmission and PPF are normal but LTP is impaired at the CA3-CA1 synapses of BDNF ${ }^{\text {Met/ }}$ Met mice. $A$, Input- output curves of the CA3-CA1 fEPSPs in 4-month-old BDNF ${ }^{\text {Met/Met }}(n=8)$ and matched wild-type mice $(n=8) . B$, Paired-pulse ratios of the CA3-CA1 fEPSPs in 4-month-old BDNF ${ }^{\text {Met/Met }}(n=8)$ and matched wild-type mice $(n=$ 8). $\boldsymbol{C}$, Examples of $\mathrm{mEPSC}$ in BDNF ${ }^{\text {Met/Met }}(n=10)$ and matched wild-type mice $(n=10)$. $\boldsymbol{D}, \boldsymbol{E}$, Cumulative probability distribution of interevent interval $(\boldsymbol{D})$ and amplitude $(\boldsymbol{E})$ of mEPSCs in BDNF Met/Met and matched wild-type mice. $\boldsymbol{F}$, TBSinduced LTP at the CA3-CA1 synapses of 1-month-old BDNF ${ }^{\text {Met/Met }}(n=8)$ and matched wild-type mice $(n=7)$. $\mathbf{G}$, TBS-induced LTP at the CA3-CA1 synapses of 4-month-old BDNF ${ }^{\text {Met/Met }}(n=8)$ and matched wild-type mice $(n=8)$. BDNF $^{\text {Met/Met }}$ and wild-type groups that did not receive TBS showed stable fEPSP slope during the course of recording. Inset, Examples of fEPSP recordings before TBS and at $180 \mathrm{~min}$ after TBS.

consisting of the following (in $\mathrm{mm}$ ): $\mathrm{NaCl}$ (118), $\mathrm{KCl}$ (4.5), glucose (10), $\mathrm{NaH}_{2} \mathrm{PO}_{4}(1), \mathrm{CaCl}_{2}(2), \mathrm{MgCl}_{2}(2)$, and $\mathrm{NaHCO}_{3}$ (25) (aerated by $95 \% \mathrm{O}_{2} / 5 \% \mathrm{CO}_{2}$, pH 7.4). CA1 field EPSPs (fEPSPs) were recorded with a glass electrode filled with $2 \mathrm{M} \mathrm{NaCl}$ by stimulating the Schaffer collateral fibers through a concentric bipolar electrode (FHC). Basal synaptic neurotransmission was studied by plotting stimulus strength against fEPSP slope to generate input-output relations. Paired-pulse facilitation (PPF) was defined as the second slope divided by the first. For the LTP and long-term depression (LTD) measurements, a $15 \mathrm{~min}$ baseline was recorded every minute at an intensity that evoked a response $\sim 35 \%$ of the maximum response. LTP was induced using a theta-burst stimulation (TBS, 4 pulses at $100 \mathrm{~Hz}$, with the bursts repeated at $5 \mathrm{~Hz}$ and each tetanus including three 10-burst trains separated by $15 \mathrm{~s}$ ) (Serulle et al., 2007). LTD was induced by application of 900 pulses at $1 \mathrm{~Hz}$ (Massey and Bashir, 2007). (S)-3,5-Dihydroxyphenylglycine hydrate (DHPG)-LTD was induced by bath perfusion of DHPG $(100 \mu \mathrm{M})$ for $10 \mathrm{~min}$ (Fitzjohn et al., 1999; Kumar and Foster, 2007).

Whole-cell recording. Postnatal day 21 (P21)-P25 mice were killed by decapitation. The brains were quickly removed and placed in ice-cold ACSF consisting of the following (in mM): $\mathrm{NaCl}$ (118), $\mathrm{KCl}$ (2.5), $\mathrm{CaCl}_{2}$ (3), $\mathrm{MgCl}_{2}$ (1), $\mathrm{NaHCO}_{3}(26), \mathrm{NaH}_{2} \mathrm{PO}_{4}(1)$, and D-glucose (10), osmolarity adjusted to
$325 \mathrm{mOsm}$ and aerated by $95 \% \mathrm{O}_{2} / 5 \% \mathrm{CO}_{2}, \mathrm{pH} 7.4$. Transverse hippocampal slices $(300 \mu \mathrm{m})$ were cut using a vibratome (Campden Instruments) and kept submerged in ACSF in a slice preincubator at room temperature for at least $1 \mathrm{~h}$ to allow for recovery. A single slice was then transferred to a recording chamber in which it was held submerged by a nylon net at $32^{\circ} \mathrm{C}$ with a TC324B in-line solution heater and controller (Warner Instruments). The chamber was continuously perfused by ACSF at a constant rate of 2 $\mathrm{ml} / \mathrm{min}$. The CA1 pyramidal neurons were visualized using video-enhanced infrared differential interference contrast microscopy (Hamamatsu C5405) with an Olympus BX50WI upright microscope fitted with $40 \times$ long working distance water-immersion objective. Patch electrodes (4-6 M $\Omega$ ) were filled with an intracellular pipette solution consisting of the following (in mM): CsCl (145), HEPES (10), EGTA (0.5), QX-314 (5), and MgATP (5). Osmolarity was adjusted to $290 \mathrm{mOsm}$ with sucrose, and $\mathrm{pH}$ was adjusted to 7.4 with $\mathrm{CsOH}$. NMDA EPSCs were recorded at $+40 \mathrm{mV}$ in the presence of glycine (1 $\mu \mathrm{M}), \mathrm{GABA}_{\mathrm{A}}$ receptor antagonist bicuculline (10 $\mu \mathrm{M})$, and AMPA receptor antagonist NBQX $(10 \mu \mathrm{M}$, 2,3-dioxo-6-nitro-1,2,3,4-tetrahydrobenzo[f]quinoxaline-7-sulfonamide disodium salt). NonNMDA EPSCs were recorded at $-60 \mathrm{mV}$ in the presence of bicuculline $(10 \mu \mathrm{M})$ and NMDA receptor antagonist D-APV $(50 \mu \mathrm{M})$. Recordings were made using an Axopatch 200B amplifier (Molecular Devices) and digitized by Digidata 1440 A (Molecular Devices). Stimulating electrodes (concentric bipolar electrodes, FHC) were placed at the Schaffer collaterals to evoke EPSCs every 20 s using a Digital stimulator PG4000A (Cygnus Technology) and stimulus isolator A365 (World Precision Instruments). Miniature EPSCs (mEPSCs) were recorded in the presence of bicuculline $(10 \mu \mathrm{m})$ and tetrodotoxin (1 $\mu \mathrm{m})$ using an electrode solution containing the following (in mm): potassium gluconate (130), $\mathrm{KCl}$ (10), $\mathrm{MgCl}_{2}$ (5), MgATP (5), EGTA (0.5), HEPES (5), osmolarity adjusted $290 \mathrm{mOsm}$ with sucrose and $\mathrm{pH}$ adjusted to 7.4 with $\mathrm{KOH}$. Recordings were rejected when series resistance or holding current changed by $10 \%$.

Statistics. Results were expressed as mean \pm SEM. Two-way ANOVA followed by post hoc comparison was used for statistical analysis. The level of significance was $p<0.05$.

\section{Results}

CA3-CA1 LTP is altered in BDNF Met/Met $^{\text {mice }}$

As the BDNF Val66Met polymorphism has been associated with impairments in hippocampus-dependent memory (Egan et al., 2003; Chen et al., 2006), we examined whether BDNF ${ }^{\text {Met/Met }}$ mice showed any effect on basal synaptic neurotransmission in the hippocampus. We recorded the slope of fEPSPs in CAl by stimulating the Schaffer collaterals in 4-month-old BDNF ${ }^{\mathrm{Met} / \mathrm{Met}}$ mice and matched wild-type mice. The input-output relationship of fEPSP slope in $\mathrm{BDNF}^{\mathrm{Met} / \mathrm{Met}}$ mice and wild-type mice were not statistically different (Fig. 1A) (two-way ANOVA, $p>0.05$ ). These results suggest that the BDNF Val66Met polymorphism does not markedly affect basal synaptic neurotransmission at the CA3-CA1 synapses.

Next, we examined PPF, a short-term plasticity that reflect a presynaptic mechanism (Hess et al., 1987; Zucker, 1989; Chen et al., 2004). The PPF in BDNF ${ }^{\text {Met/Met }}$ mice and wild-type mice was not statistically different, suggesting that the BDNF Val66Met 


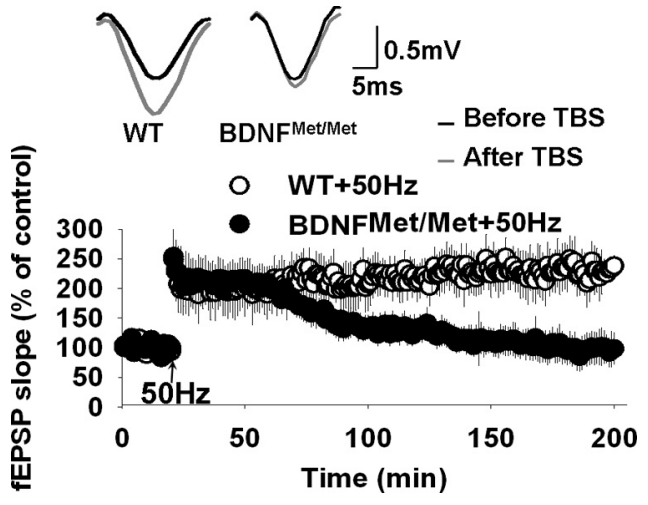

Figure 2. BDNF ${ }^{\text {Met/Met }}$ mice exhibit an altered NMDA receptor-dependent postsynaptic LTP at the CA3-CA1 synapses. The graph shows $50 \mathrm{~Hz}$-induced LTP at the CA3-CA1 synapses of 4-month-old BDNF ${ }^{\text {Met/Met }}(n=8)$ and matched wild-type mice $(n=8)$. BDNF ${ }^{\text {Met/Met }}$ and wild-type groups that did not receive the $50 \mathrm{~Hz}$ stimulation showed stable fEPSP slope during the course of recording. Inset, Examples of fEPSP recordings before $50 \mathrm{~Hz}$ stimulation and at 180 min after $50 \mathrm{~Hz}$ stimulation.

polymorphism did not affect presynaptic release probability at the CA3-CA1 synapses (Fig. 1B) (two-way ANOVA, $p>0.05$ ). Consistently, we did not find any significant difference in either frequency or amplitude of mEPSCs recorded from the CA1 pyramidal neurons of $\mathrm{BDNF}^{\mathrm{Met} / \mathrm{Met}}$ and matched wild-type mice (Fig. 1C-E).

To examine activity-dependent synaptic plasticity in $\mathrm{BDNF}^{\mathrm{Met} / \mathrm{Met}}$ mice, we compared the effect of theta-burst stimulation (TBS) on LTP in BDNF ${ }^{\mathrm{Met} / \mathrm{Met}}$ and wild-type mice. TBSinduced LTP requires activation of NMDA receptors and is believed to involve both presynaptic and postsynaptic mechanisms (Malinow, 1991; Malenka and Nicoll, 1999; Morgan and Teyler, 2001; Zakharenko et al., 2001, 2003). Although the application of TBS produced robust LTP in 1-month-old wild-type mice, LTP in BDNF ${ }^{\text {Met/Met }}$ mice was virtually absent (Fig. $1 F$ ) $\left(F_{(1,13)}=8.44\right.$, two-way ANOVA, $\left.p<0.01\right)$. These results suggest that the BDNF Val66Met polymorphism affected LTP in the hippocampus. We also examined TBS-induced LTP in 4-month-old $\mathrm{BDNF}^{\mathrm{Met} / \mathrm{Met}}$ and age-matched wild-type mice. In these older animals, the BDNF ${ }^{\text {Met/Met }}$ mice showed an early TBS-induced potentiation that declined to baseline within $2 \mathrm{~h}$. Similar to the LTP in 1-month-old mice, however, we observed significantly lower levels of late LTP in BDNF ${ }^{\mathrm{Met} / \mathrm{Met}}$ mice compared to the wild-type mice (Fig. $1 G)\left(F_{(1,14)}=5.9\right.$, two-way ANOVA, $p<$ $0.01)$ BDNF $^{\mathrm{Met} / \mathrm{Met}}$ and wild-type groups that did not receive TBS showed stable fEPSP slope during the course of recording (data not shown).

To study the effect of BDNF Val66Met polymorphism on LTP further, we compared the effect of $50 \mathrm{~Hz}$ stimulation (three $1 \mathrm{~s}$ trains of $50 \mathrm{~Hz}$ stimulation applied every $20 \mathrm{~s}$ )-induced LTP in 4-month-old BDNF ${ }^{\mathrm{Met} / \mathrm{Met}}$ mice and wild-type mice. Similar to the LTP induced by TBS, $50 \mathrm{~Hz}$-induced LTP in BDNF ${ }^{\mathrm{Met} / \mathrm{Met}}$ mice was significantly lower than that in wild-type mice (Fig. 2) $\left(F_{(1,14)}=5.3\right.$, two-way ANOVA, $\left.p<0.01\right)$. BDNF ${ }^{\mathrm{Met} / \mathrm{Met}}$ and wild-type groups that did not receive the $50 \mathrm{~Hz}$ stimulation showed stable fEPSP slope during the course of recording (data not shown). This $50 \mathrm{~Hz}$ protocol has been reported to induce NMDA receptor-dependent postsynaptic LTP at the CA3-CA1 synapses (Zakharenko et al., 2001, 2003). The results described above confirm that the BDNF Val66Met polymorphism causes a major reduction in hippocampal LTP.
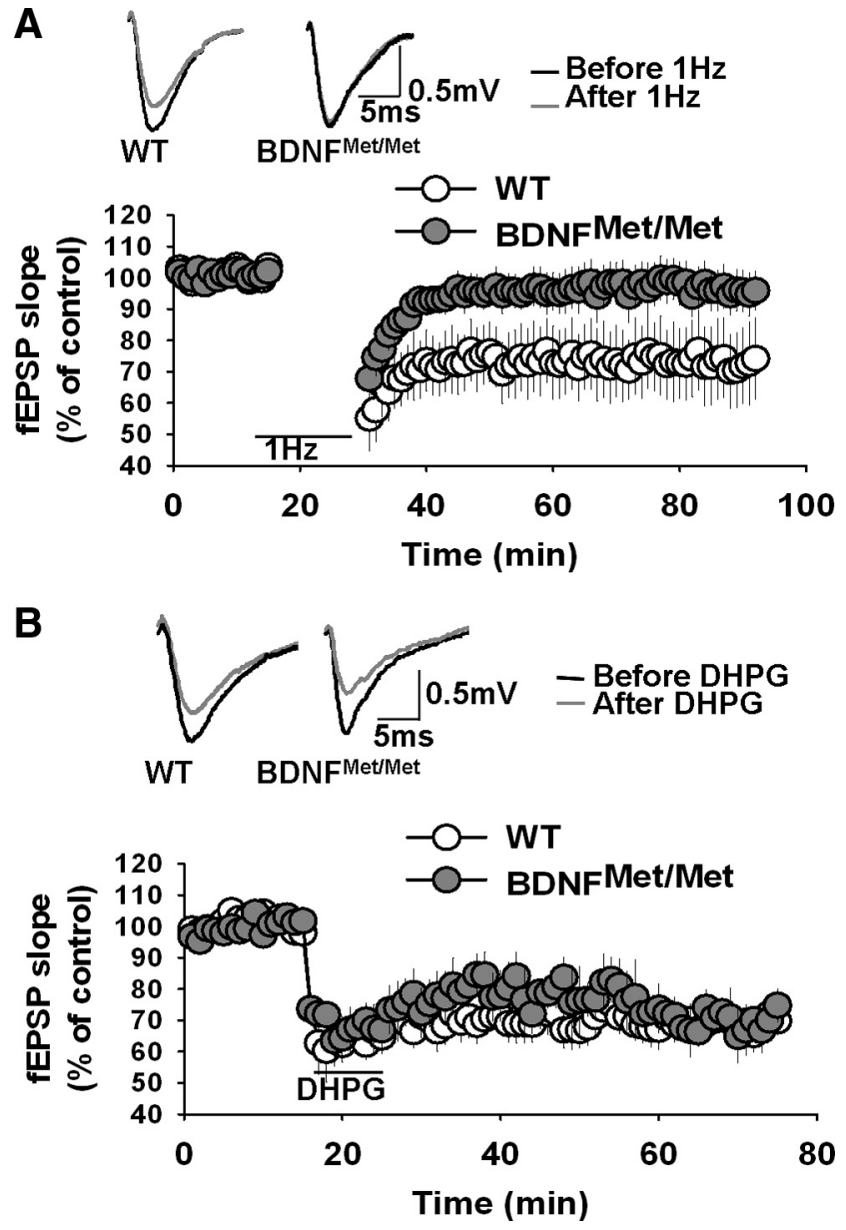

Figure 3. The BDNF Val66Met polymorphism interferes with NMDA receptor-dependent LTD but not mGluR-dependent LTD. A, Low-frequency stimulation (1 Hz)-induced LTD at the CA3-CA1 synapses of 1-month-old BDNF ${ }^{\text {Met/Met }}(n=7)$ and matched wild-type mice $(n=9)$. $B$, DHPG-induced LTD at the CA3-CA1 synapses of 1-month-old BDNF ${ }^{\text {Met/Met }}(n=7)$ and matched wild-type mice $(n=7)$. Inset, Examples of fEPSP recordings before $1 \mathrm{~Hz}$ stimulation/ DHPG application and at $60 \mathrm{~min}$ after $1 \mathrm{~Hz}$ stimulation/DHPG application.

The BDNF Val66Met polymorphism selectively interferes with NMDA receptor-dependent LTD

Similar to the purported role of LTP in hippocampus-dependent cognitive functions, LTD is also believed to play a role in hippocampal functions (Bear and Abraham, 1996). To examine whether the BDNF Val66Met polymorphism has any effect upon LTD at the CA3-CA1 synapses, we used an established induction protocol for NMDA receptor-dependent LTD, application of 900 pulses at $1 \mathrm{~Hz}$ (Massey and Bashir, 2007). Application of $1 \mathrm{~Hz}$ stimulation produced reliable LTD in 1-month-old wild-type mice (Fig. 3A) (repeated-measures ANOVA, $p<0.01$ ). However, LTD in BDNF ${ }^{\text {Met/Met }}$ slices was significantly lower than that in the wild-type slices (Fig. $3 A)\left(F_{(1,15)}=6.42\right.$, two-way ANOVA, $p<0.01$ ). These results suggested that the BDNF Val66Met polymorphism affected not only LTP, but also LTD at the CA3-CA1 synapse.

To examine whether the effect of the BDNF Val66Met polymorphism was selective for NMDA receptor-dependent LTD, we studied mGluR-dependent LTD in BDNF ${ }^{\text {Met/Met }}$ mice. Application of mGluR agonist DHPG normally induces LTD at the CA3-CA1 synapse in young animals in an NMDA receptor-independent fashion (Fitzjohn et al., 1999; Kumar and Foster, 2007). Application of 100 $\mu \mathrm{M}$ DHPG for $10 \mathrm{~min}$ induced reliable LTD in the wild-type mice as 

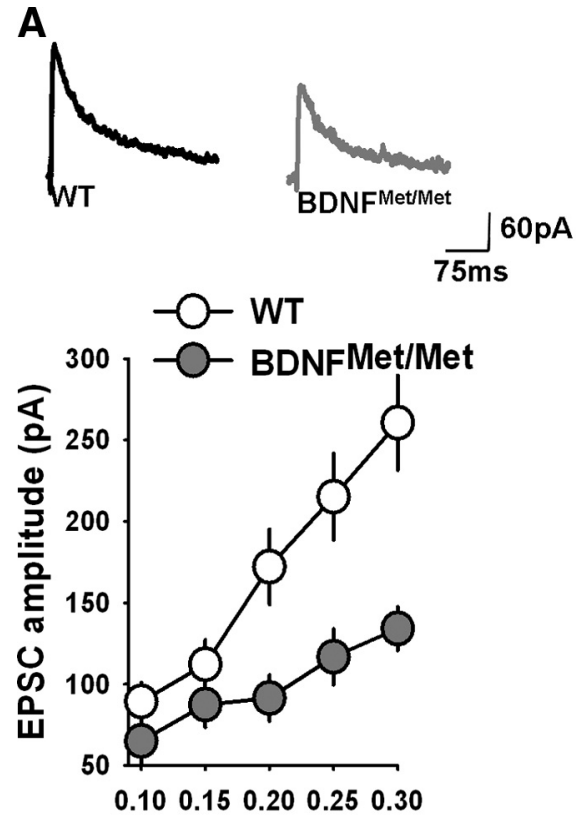

Stimulation intensity $(\mathrm{mA})$
B

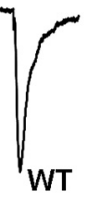

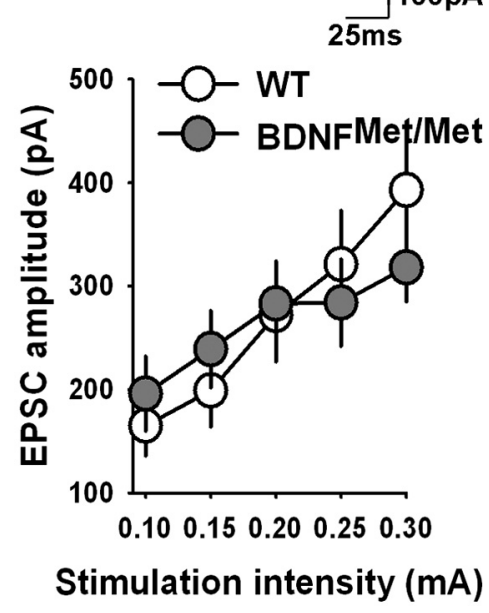

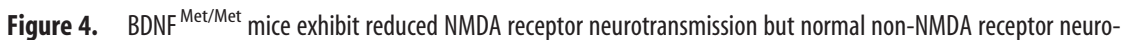
transmission in the CA1 pyramidal neurons. $\boldsymbol{A}$, Average NMDA EPSC amplitude in the CA1 pyramidal neurons of BDNF ${ }^{\text {Met/Met }}$ $(n=8)$ and matched wild-type mice $(n=8)$. $\boldsymbol{B}$, Average non-NMDA EPSC amplitude in the CA1 pyramidal neurons of $\operatorname{BDNF}^{\text {Met/Met }}(n=8)$ and matched wild-type mice $(n=8)$. Inset, Examples of EPSC recordings.

reported previously (Fig. 3B) (repeated-measures ANOVA, $p<$ 0.01) (Kumar and Foster, 2007). Interestingly, DHPG-induced LTD in BDNF ${ }^{\text {Met/Met }}$ mice was not significantly different from wild-type mice (Fig. 3B) (two-way ANOVA, $p>0.05$ ). Thus, the BDNF Val66Met polymorphism selectively reduces NMDA receptordependent LTD but not the mGluR-dependent LTD at the hippocampal CA3-CA1 synapses.

$\mathrm{BDNF}^{\text {Met/Met }}$ mice exhibit reduced NMDA receptor neurotransmission in the CA1 pyramidal neurons

The aforementioned LTP and LTD experiments strongly suggested that the BDNF Val66Met polymorphism affects NMDA receptor-dependent synaptic plasticity at the CA3-CA1 synapses. Therefore, it is possible that the BDNF Val66Met polymorphism alters NMDA receptor neurotransmission at the CA3-CA1 synapses. To determine whether NMDA receptor neurotransmission is modified at the CA3-CA1 synapses of BDNF ${ }^{\text {Met/Met }}$ mice, we measured NMDA EPSC amplitude in the CA1 pyramidal neurons by whole-cell recording at $+40 \mathrm{mV}$ in the presence of bicuculline (to block $\mathrm{GABA}_{\mathrm{A}}$ receptors) and $\mathrm{NBQX}$ (to block AMPA receptors) by stimulation of the Schaffer collaterals. The average amplitudes of NMDA EPSCs in BDNF ${ }^{\text {Met/Met }}$ mice were significantly lower than those observed in wild-type mice (Fig. $4 A)\left(F_{(1,14)}=11.2\right.$, two-way ANOVA, $p<0.01)$, suggesting reduced NMDA receptor neurotransmission in the CA1 pyramidal neurons of BDNF ${ }^{\text {Met/Met }}$ mice. The input-output analysis of fEPSPs indicated that the BDNF Val66Met polymorphism did not affect non-NMDA receptor neurotransmission at the CA3-CA1 synapses (Fig. 1A). EPSCs evoked at $-60 \mathrm{mV}$ in the presence of bicuculline and D-APV (to block NMDA receptors) in $\mathrm{BDNF}^{\mathrm{Met} / \mathrm{Met}}$ mice were not significantly different from age-matched wild-type animals, suggesting that non-NMDA receptor neurotransmission is normal in the CA1 pyramidal neurons of BDNF ${ }^{\text {Met/Met }}$ mice (Fig. $4 B$ ) (two-way ANOVA, $p>0.05$ ). The lack of evidence for modification of non-NMDA receptor neu-

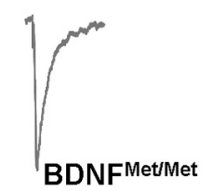

$100 \mathrm{pA}$ rotransmission further supports an NMDA receptor-specific impairment of synaptic functions in $\mathrm{BDNF}^{\mathrm{Met} / \mathrm{Met}}$ mice.

\section{Discussion}

Recent human and animal studies have suggested a role for the BDNF Val66Met polymorphism in hippocampus-dependent cognitive functions (Egan et al., 2003; Hariri et al., 2003; Chen et al., 2006). Therefore, we examined whether and how the BDNF Val66Met polymorphism affects hippocampal neurotransmission and synaptic plasticity using $\mathrm{BDNF}^{\mathrm{Met} / \mathrm{Met}}$ mice. Both young and adult $\mathrm{BDNF}^{\mathrm{Met} / \mathrm{Met}}$ mice exhibited a decrease in TBS-induced LTP at the CA3-CA1 synapses. Earlier studies demonstrated that TBSinduced LTP required activation of NMDA receptors and involved both presynaptic and postsynaptic mechanisms (Malinow, 1991; Malenka and Nicoll, 1999; Morgan and Teyler, 2001; Zakharenko et al., 2001, 2003). Also, BDNF release was involved in TBSinduced LTP (Patterson et al., 2001; Zakharenko et al., 2003). Results from our experiments using a postsynaptic LTP induced by $50 \mathrm{~Hz}$ stimulation revealed that this form of LTP is also impaired in BDNF ${ }^{\text {Met/Met }}$ mice. An earlier study in CA3-CA1 restricted BDNF knock-out mice showed normal 50 Hz-induced LTP (Zakharenko et al., 2003). In contrast, unrestricted BDNF knock-out mice showed impairment of $100 \mathrm{~Hz}$ induced LTP, an experimental protocol similar to $50 \mathrm{~Hz}$-induced LTP (Korte et al., 1995, 1996; Patterson et al., 1996). Therefore, it is possible that the difference in $50 \mathrm{~Hz}$-induced LTP in BDN$\mathrm{F}^{\text {Met/Met }}$ mice and CA3-CA1 restricted BDNF knock-out mice is due to the global reduction of BDNF signaling in $\mathrm{BDNF}^{\text {Met/Met }}$ mice (Zakharenko et al., 2003).

Consistent with a reduction in NMDA receptor-dependent LTP in BDNF ${ }^{\text {Met/Met }}$ mice, we also observed a decrease in NMDA receptor-dependent LTD in these mice. A postsynaptic increase in calcium through NMDA receptors is critical for the induction of low-frequency stimulation-induced LTD (Malenka and Bear, 2004). Endocytosis of the GluR2 subunit of AMPA receptors in response to activation of NMDA receptors is believed to be involved in low-frequency stimulation-induced LTD (Lee et al., 2002; Malenka and Bear, 2004). The effect of BDNF Val66Met polymorphism on LTD is specific, since mGluR-dependent LTD was unaffected in BDNF ${ }^{\text {Met/Met }}$ mice. LTD in the hippocampus can be mediated by the activation of group 1 mGluR receptors, which is dependent upon an elevation of intracellular calcium and is independent of NMDA receptor activation (Kemp and Bashir, 2001; Gladding et al., 2009). Earlier studies showed group $1 \mathrm{mGluR}$ receptor-initiated LTD in a clathrin-dependent manner postsynaptically (Xiao et al., 2001). The selective reduction of NMDA receptor-dependent LTD, and not mGluR-dependent LTD, suggests that the BDNF Val66Met polymorphism has a specific effect on hippocampal plasticity.

The molecular pathway by which BDNF modulates NMDA receptor function is not clearly understood. BDNF can enhance phosphorylation of NMDA receptors and NMDA receptor activity (Suen et al., 1997; Levine et al., 1998; Lin et al., 1998; Crozier et al., 2008). Also, BDNF can regulate trafficking and expression of 
NMDA receptors (Caldeira et al., 2007). It is possible that the BDNF Val66Met polymorphism affects aforementioned regulation of NMDA receptor functions resulting in impaired synaptic plasticity. However, we cannot rule out the potential role of acute activity-dependent release of BDNF in altered synaptic plasticity in BDNF ${ }^{\text {Met/Met }}$ mice. Future studies will be necessary to investigate the effect of the BDNF Val66Met polymorphism on synapsespecific release of BDNF and its direct role in synaptic plasticity.

In conclusion, the present study demonstrates that the BDNF Val66Met polymorphism has functional consequences in NMDA receptor neurotransmission and synaptic plasticity in the hippocampus. Alterations in hippocampal synaptic function are likely to play a role in cognitive deficits associated with the BDNF Val66Met polymorphism.

\section{References}

Bear MF, Abraham WC (1996) Long-term depression in hippocampus. Annu Rev Neurosci 19:437-462.

Bekinschtein P, Cammarota M, Izquierdo I, Medina JH (2008) BDNF and memory formation and storage. Neuroscientist 14:147-156.

Caldeira MV, Melo CV, Pereira DB, Carvalho RF, Carvalho AL, Duarte CB (2007) BDNF regulates the expression and traffic of NMDA receptors in cultured hippocampal neurons. Mol Cell Neurosci 35:208-219.

Chen G, Harata NC, Tsien RW (2004) Paired-pulse depression of unitary quantal amplitude at single hippocampal synapses. Proc Natl Acad Sci U S A 101:1063-1068.

Chen ZY, Ieraci A, Teng H, Dall H, Meng CX, Herrera DG, Nykjaer A, Hempstead BL, Lee FS (2005) Sortilin controls intracellular sorting of brain-derived neurotrophic factor to the regulated secretory pathway. J Neurosci 25:6156-6166.

Chen ZY, Jing D, Bath KG, Ieraci A, Khan T, Siao CJ, Herrera DG, Toth M, Yang C, McEwen BS, Hempstead BL, Lee FS (2006) Genetic variant BDNF (Val66Met) polymorphism alters anxiety-related behavior. Science 314:140-143.

Crozier RA, Bi C, Han YR, Plummer MR (2008) BDNF modulation of NMDA receptors is activity dependent. J Neurophysiol 100:3264-3274.

Egan MF, Kojima M, Callicott JH, Goldberg TE, Kolachana BS, Bertolino A, Zaitsev E, Gold B, Goldman D, Dean M, Lu B, Weinberger DR (2003) The BDNF val66met polymorphism affects activity-dependent secretion of BDNF and human memory and hippocampal function. Cell 112:257-269

Fitzjohn SM, Kingston AE, Lodge D, Collingridge GL (1999) DHPGinduced LTD in area CA1 of juvenile rat hippocampus; characterisation and sensitivity to novel mGlu receptor antagonists. Neuropharmacology 38:1577-1583.

Gladding CM, Fitzjohn SM, Molnár E (2009) Metabotropic glutamate receptor-mediated long-term depression: molecular mechanisms. Pharmacol Rev 61:395-412.

Hariri AR, Goldberg TE, Mattay VS, Kolachana BS, Callicott JH, Egan MF, Weinberger DR (2003) Brain-derived neurotrophic factor val66met polymorphism affects human memory-related hippocampal activity and predicts memory performance. J Neurosci 23:6690-6694.

Hess G, Kuhnt U, Voronin LL (1987) Quantal analysis of paired-pulse facilitation in guinea pig hippocampal slices. Neurosci Lett 77:187-192.

Kemp N, Bashir ZI (2001) Long-term depression: a cascade of induction and expression mechanisms. Prog Neurobiol 65:339-365.

Korte M, Carroll P, Wolf E, Brem G, Thoenen H, Bonhoeffer T (1995) Hippocampal long-term potentiation is impaired in mice lacking brainderived neurotrophic factor. Proc Natl Acad Sci U S A 92:8856-8860.

Korte M, Griesbeck O, Gravel C, Carroll P, Staiger V, Thoenen H, Bonhoeffer $\mathrm{T}$ (1996) Virus-mediated gene transfer into hippocampal CAl region restores long-term potentiation in brain-derived neurotrophic factor mutant mice. Proc Natl Acad Sci U S A 93:12547-12552.

Kumar A, Foster TC (2007) Shift in induction mechanisms underlies an age-dependent increase in DHPG-induced synaptic depression at CA3 CA1 synapses. J Neurophysiol 98:2729-2736.

Lee SH, Liu L, Wang YT, Sheng M (2002) Clathrin adaptor AP2 and NSF interact with overlapping sites of GluR2 and play distinct roles in AMPA receptor trafficking and hippocampal LTD. Neuron 36:661-674.
Levine ES, Crozier RA, Black IB, Plummer MR (1998) Brain-derived neurotrophic factor modulates hippocampal synaptic transmission by increasing N-methyl-D-aspartic acid receptor activity. Proc Natl Acad Sci U S A 95:10235-10239.

Lin SY, Wu K, Levine ES, Mount HT, Suen PC, Black IB (1998) BDNF acutely increases tyrosine phosphorylation of the NMDA receptor subunit $2 \mathrm{~B}$ in cortical and hippocampal postsynaptic densities. Brain Res Mol Brain Res 55:20-27.

Malenka RC, Bear MF (2004) LTP and LTD: an embarrassment of riches. Neuron 44:5-21.

Malenka RC, Nicoll RA (1999) Long-term potentiation-a decade of progress? Science 285:1870-1874.

Malinow R (1991) Transmission between pairs of hippocampal slice neurons: quantal levels, oscillations, and LTP. Science 252:722-724.

Massey PV, Bashir ZI (2007) Long-term depression: multiple forms and implications for brain function. Trends Neurosci 30:176-184.

Minichiello L, Korte M, Wolfer D, Kühn R, Unsicker K, Cestari V, RossiArnaud C, Lipp HP, Bonhoeffer T, Klein R (1999) Essential role for TrkB receptors in hippocampus-mediated learning. Neuron 24:401-414.

Minichiello L, Calella AM, Medina DL, Bonhoeffer T, Klein R, Korte M (2002) Mechanism of TrkB-mediated hippocampal long-term potentiation. Neuron 36:121-137.

Morgan SL, Teyler TJ (2001) Electrical stimuli patterned after the thetarhythm induce multiple forms of LTP. J Neurophysiol 86:1289-1296.

Patterson SL, Abel T, Deuel TA, Martin KC, Rose JC, Kandel ER (1996) Recombinant BDNF rescues deficits in basal synaptic transmission and hippocampal LTP in BDNF knockout mice. Neuron 16:1137-1145.

Patterson SL, Pittenger C, Morozov A, Martin KC, Scanlin H, Drake C, Kandel ER (2001) Some forms of cAMP-mediated long-lasting potentiation are associated with release of BDNF and nuclear translocation of phospho-MAP kinase. Neuron 32:123-140.

Rybakowski JK (2008) BDNF gene: functional Val66Met polymorphism in mood disorders and schizophrenia. Pharmacogenomics 9:1589-1593.

Serulle Y, Zhang S, Ninan I, Puzzo D, McCarthy M, Khatri L, Arancio O, Ziff EB (2007) A GluR1-cGKII interaction regulates AMPA receptor trafficking. Neuron 56:670-688.

Soliman F, Glatt CE, Bath KG, Levita L, Jones RM, Pattwell SS, Jing D, Tottenham N, Amso D, Somerville LH, Voss HU, Glover G, Ballon DJ, Liston C, Teslovich T, Van Kempen T, Lee FS, Casey BJ (2010) A genetic variant BDNF polymorphism alters extinction learning in both mouse and human. Science 327:863-866.

Suen PC, Wu K, Levine ES, Mount HT, Xu JL, Lin SY, Black IB (1997) Brain-derived neurotrophic factor rapidly enhances phosphorylation of the postsynaptic N-methyl-D-aspartate receptor subunit 1. Proc Natl Acad Sci U S A 94:8191-8195.

Tyler WJ, Pozzo-Miller LD (2001) BDNF enhances quantal neurotransmitter release and increases the number of docked vesicles at the active zones of hippocampal excitatory synapses. J Neurosci 21:4249-4258.

Ventriglia M, Bocchio Chiavetto L, Benussi L, Binetti G, Zanetti O, Riva MA, Gennarelli M (2002) Association between the BDNF 196 A/G polymorphism and sporadic Alzheimer's disease. Mol Psychiatry 7:136-137.

Verhagen M, van der Meij A, van Deurzen PA, Janzing JG, Arias-Vásquez A, Buitelaar JK, Franke B (2010) Meta-analysis of the BDNF Val66Met polymorphism in major depressive disorder: effects of gender and ethnicity. Mol Psychiatry 15:260-271.

Xiao MY, Zhou Q, Nicoll RA (2001) Metabotropic glutamate receptor activation causes a rapid redistribution of AMPA receptors. Neuropharmacology 41:664-671.

Yano H, Ninan I, Zhang H, Milner TA, Arancio O, Chao MV (2006) BDNFmediated neurotransmission relies upon a myosin VI motor complex. Nat Neurosci 9:1009-1018.

Zakharenko SS, Zablow L, Siegelbaum SA (2001) Visualization of changes in presynaptic function during long-term synaptic plasticity. Nat Neurosci 4:711-717.

Zakharenko SS, Patterson SL, Dragatsis I, Zeitlin SO, Siegelbaum SA, Kandel ER, Morozov A (2003) Presynaptic BDNF required for a presynaptic but not postsynaptic component of LTP at hippocampal CA1-CA3 synapses. Neuron 39:975-990.

Zucker RS (1989) Short-term synaptic plasticity. Annu Rev Neurosci 12:1331. 